\title{
RESENHA
}

CAIMARI, Lila. La vida en el archivo: goces, tedios y desvíos en el oficio de la historia. Ciudad Autónoma de Buenos Aires: Siglo XXI Editores Argentina, 2017. 144 p.

Meily Assbú Linhales

UFMG

meily_linhales@yahoo.com.br

\section{SOBRE O MUNDO DOS E NOS ARQUIVOS}

Há livros que nos enlaçam pelo título e esse foi um deles. Creio que o meu trabalho cotidiano como coordenadora de acervos em um Centro de Memória, tornou tal captura algo mais aguçado. Não menos importante, foi uma nota breve sobre o livro, divulgada pela Profa. Dra. Luciana Quillet Heymann, com quem tive a honra de realizar meu estágio de pósdoutoramento no CPDOC/FGV, entre 2013-2014, investigando processos de organização de Arquivos Pessoais de Professores. Tão logo pude ter o livro em mãos, as expectativas se confirmaram. Trata-se de uma obra indicada a todos que passam boa parte de suas vidas profissionais nos arquivos e na tessitura da escrita da história.

Lila Caimari, historiadora argentina ${ }^{1}$, é a autora de La vida en el archivo: goces, tedios y desvíos en el oficio de la historia. A obra organiza-se a partir de um texto introdutório, seguido de outros nove de tamanhos e estruturas bastante diversas. Entre ensaios, artigos preparados para eventos acadêmicos e textos que muito se aproximam de excelentes cadernos de campo, o conjunto da obra é um convite à reflexão sobre o ofício do historiador, na seus estreita relação com as fontes, presentes ou ausentes, nos arquivos. Pode-se dizer que o livro de Caimari e as reflexões nele contidas são uma espécie de realce aos bastidores de uma investigação, ao encontro primeiro com jornais, livros, manuais, coleções de leis, cartas, etc. em estados variados de conservação e organização. A busca dos itens ausentes nos acervos, a constante negociação com arquivistas, documentalistas e outros guardiões de vestígios, a promessa de que no dia seguinte a coleção sob consulta ainda estará lá! A autora nos reporta a estes lugares pouco revelados do trabalho acadêmico e intelectual, com um convite para "acompañar el processo que va del archivo dado (público o provado, material o digital) ao archivo próprio (el que se construye para um proyecto)" (2017, p. 15) provocando o envolvimento do leitor com a

\footnotetext{
${ }^{1}$ Graduada pela Universidad Nacional de La Plata, realizou seu doutoramento no Instituto de Estudos políticos de Paris. É investigadora do CONICET e docente na Pós-graduação em História da Universidad de San Andrés.
} 
multiplicidades de posições e decisões implícitas nessa tarefa. Também nos faz lembrar Michel de Certeau, quanto afirma que o historiador é o poeta do detalhe.

São raros os pesquisadores que se dispõem a mostrar, narrar em minúcias, os movimentos de vai-e-vem presentes nos processo de busca, levantamento e organização de fontes para as pesquisas históricas. Em geral, é como se tais elementos, com seus "gozos, desvios e tédios", não estivessem presentes nos percursos investigativos, não merecessem ser dados a ver. Entretanto, bem sabemos que são capazes de provocar mudanças de rotas, lentidões, fracassos e, também, abrir portas não antevistas. Acervos organizados, ou aqueles em completo estado de desconstrução, já provocaram, para muitos pesquisadores, experiência de uma tarde de lentas leituras, sem ver o tempo passar e sem saber como continuar...

Algo similar é o que a autora nos apresenta, com arte, sensibilidade e respeitáveis análises de ordem teórico-conceitual e metodológica. Não menos importante é o seu compromisso e engajamento no debate sobre políticas de acervo (ou sobre as não-políticas de acervos) com as quais nos deparamos rotineiramente. Um compromisso que desnuda a situação de precariedade na qual se encontram muitos arquivos na América Latina, alguns deles sendo sub-repticiamente enviados para o hemisfério norte, em uma espécie de "drenagem patrimonial"'.

Entre tantos pontos ressaltados por Lila Caimari a partir de suas próprias práticas, alguns parecem merecedores de maior destaque. A autora problematiza uma mudança em curso, na qual a busca pelos documentos, antes calcada em uma "economia da escassez" - da ausência de fontes, das coleções lacunares, etc. - agora parece passar para a "superabundância documental" possibilitada tecnologicamente pelo "giro digital". Agora cada vez mais distantes das salas de consulta, dos porões que abrigam caixas não catalogadas, das rotinas disciplinares das bibliotecas e dos centros de documentação, os jovens pesquisadores parecem constituir outro tipo de relação com a pesquisa. Não raro se desobrigam a respeito do contexto de origem dos documentos, transformam as pesquisas em acúmulos digitalizados e armazenados em nuvens. Parece acontecer por decorrência uma espécie de dissolução laço tátil que une o pesquisador ao passado, na medida em que as novas tecnologias modificam a experiência sensível e vital do e no trabalho empírico. A perda da aura do arquivo é um fato a merecer futuras reflexões acerca de suas consequências? Segunda Caimari, há se se considerar uma necessária integração entre as "ferramentas libertadoras, quase mágicas" dos bancos de dados e dos arquivos digitais e os saberes que se forjam nas salas de leitura de um arquivo tradicional.

Outro aspecto problematizado com autoridade no livro refere-se aos abundantes acúmulos documentais possibilitados pelas novas tecnologias. Eles demandarão ulteriores 
exercícios de desapego e um inevitavelmente savoir faire com os restos, aqui compreendidos como tudo aquilo que não participará da escrita: “después de los excesos sensuales de la acumulación, lhega el ejercicio de sobriedad y estilización” (2017, p. 11). Não se trata de uma tarefa simples, depois de um longo e intenso período de convivência com este "archivomondo", boa parte do corpus documental arrolado para uma pesquisa pode volta ao seu lugar de "mundo dormido" (2017, p. 13), podendo ser (ou não) acionado em aventuras investigativas ulteriores. A autora aborda tal assunto de forma admirável.

Sobre o sua diálogo com autores e obras de referência, Caimari nos apresenta alguns elementos da trama que constitui seu processo de formação como estudiosa de temas complexos tais como crimes, processos, prisões, castigos, etc. Do clássico "Vigiar e Punir" de Michel de Foucault - segundo ela uma espécie de "autor sagrado" nos contexto argentino dos anos oitenta - ao encontro com E. P. Thompson, Carlo Ginzburg, Natalie Zemon Davies, James Scott e Michel de Certeau, etc. a autora nos permite conhecer um percurso de amadurecimento e refinamento frente à operação historiográfica. Interroga o que denomina de "descendência submissa", ou seja, a perpetuação de esquemas interpretativos que podem se tornar "prisões conceituais", por ocuparem lugar cômodo, transformando-se, por vezes, em sobre intepretações, pouco atentas aos documentos e às suas condições de produção, suas peculiaridades e desvios. Nas palavras da autora: "el desconcierto inicial ante la dirección que me indicaba el archivo había ido dejando lugar a la convicción de los errores de (sobre)interpretación que habían marcado los trabajos disponibles” (2017, p. 43).

Estes, entre outros assuntos, foram postos aqui em realce, já que o livro em questão é um convite a outras tantas leituras e pontuações. Ao escrever sobre o lado pouco revelado do trabalho acadêmico e realizando tal feito com genialidade e humor, Lila Caimari nos convoca à reflexão permanente sobre nossas escolhas, no contextura que inventamos, para nós mesmos, quando diante dos arquivos. Neste número da RIDPHE_R que acolhe um dossiê sobre "Educação Física na Iberoamérica: história, memória e patrimônio", pareceu-me providencial a resenha desta obra. Se por um lado ela anuncia o refinamento necessário ao exercício de tornar-se historiador(a) - como tem acontecido com muitos estudiosos do campo da Educação Física -, por outro lado ela nos abraça, solidariamente, ao descortinar, com astúcias, o caráter desafiante, complexo, e nem sempre declarado, de todo trabalho com e nos arquivos. 